\title{
Aktivitas Enzim Superoksida Dismutase, Katalase, dan Glutation Peroksidase Wanita Penderita Sindrom Metabolik
}

\author{
Hery Winarsi, ${ }^{1}$ Siwi P. M. Wijayanti, ${ }^{2}$ Agus Purwanto ${ }^{3}$ \\ ${ }^{1}$ Fakultas Biologi Universitas Soedirman, ${ }^{2}$ Jurusan Kesehatan Masyarakat Fakultas Kedokteran dan \\ Ilmu-ilmu Kesehatan Universitas Soedirman, ${ }^{3}$ RSUD Margono Soekarjo Purwokerto
}

\begin{abstract}
Abstrak
Rendahnya status antioksidan endogenus memicu perkembangan kondisi sindrom metabolik (SM). Penelitian ini bertujuan untuk mengeksplorasi aktivitas enzim antioksidan superoksida dismutase (SOD), katalase, dan glutation peroksidase (GSH-PX) dalam plasma wanita penderita sindrom metabolik. Penelitian dilakukan periode MaretNovember 2010, dengan responden penelitian adalah 30 wanita yang memiliki kriteria sebagai berikut: kadar gula darah $>$ normal, body mass index $>25 \mathrm{~kg} / \mathrm{m}^{2}$, hipertrigliseridemia, high-density lipoprotein (HDL) rendah, usia $>40$ tahun, dan tinggal di Purwokerto. Seleksi responden dimulai melalui survey di poliklinik internis Rumah Sakit Umum Margono Soekarjo Purwokerto. Kepada calon responden dijelaskan tentang tujuan penelitian, kondisi SM, dan perkembangannya. Calon responden yang bersedia bergabung diminta menandatangani informed consent, diukur berat badan, tinggi badan, dan tekanan darahnya. Diambil sampel darahnya $2 \mathrm{~mL}$, intravena, ditentukan kadar glukosa darah, trigliserida, dan HDL. Bagian plasma, diuji aktivitas enzim SOD, katalase, dan GSH-PX. Data dipresentasikan sebagai rata-rata \pm standard error. Status antioksidan wanita penderita sindrom metabolik rendah, ditunjukkan oleh aktivitas SOD $379,3 \mathrm{Unit} / \mathrm{mg}$ protein, katalase 6,42 UI/mg protein, dan GSH-PX 804,9 $\mathrm{nmol} / \mathrm{g}$ protein, serta kadar malondialdehid (MDA) sebesar 2.943,4 pmol/mL. Karena itu responden perlu asupan kaya antioksidan. Simpulan, status antioksidan peroksidase sama rendah yang ditunjukkan oleh rendahnya aktivitas enzim SOD, katalase, dan glutation peroksidase. [MKB. 2012;44(1):7-12].
\end{abstract}

Kata kunci: Glutation peroksidase, katalase, sindrom metabolik, superoksida dismutase

\section{The Activity of Superoxide Dismutase, Catalase and Glutathione Peroxidase Enzymes in Metabolic Syndrome Women}

\begin{abstract}
The low endogenous antioxidant status induced development of metabolic syndrome (MetS) condition. The aim of this research was to explore superoxide dismutase (SOD), catalase (Cat), and glutathione peroxidase (GSH-PX) plasma activity on metabolic syndrome women plasma. Respondents were thirty women with blood glucose level $>$ normal, body mass index $>25 \mathrm{~kg} / \mathrm{m}^{2}$, hypertrigliceridemic, low level cholesterol-high-density lipoprotein (HDL), the age $>40$ years and live in Purwokerto. Respondents' selection was started by a survey at internist polyclinic of Margono Soekarjo General Hospital Purwokerto. They were motivated and given an explanation about aim of the research, their diseases and development risk who were willing to be respondents were asked to sign the informed consent. Then, their body weight, height and blood pressure were measured. Their blood sample of $2 \mathrm{~mL}$ were taken intravenously and tested for blood glucose, triglyceride and HDL levels. Plasma was tested for the activities of SOD, Cat and GSH-PX enzymes. Presented data was mean \pm standard error. The antioxidant status of MetS women were low, showed on the activities of SOD, catalase, and glutathione peroxidase enzyme were 379.3 Unit/ $\mathrm{mg}$ protein, $6.42 \mathrm{UI} / \mathrm{mL}, 804.9 \mathrm{nmol} / \mathrm{g}$ protein respectively, and malondialdehyde (MDA) level was $2,943.4 \mathrm{pmol} /$ $\mathrm{mL}$. Therefore, they need food enrich antioxidant. In conclusions, peroxidase antioxidant status was similar shown by low SOD, catalase and glutathione peroxidase enzyme activity, [MKB. 2012;44(1):7-12].
\end{abstract}

Key words: Catalase, glutathione peroxidase, metabolic syndrome, superoxide dismutase 


\section{Pendahuluan}

Obesitas merupakan ciri utama dalam sindrom metabolik (SM), disertai hiperglikemia, hipertrigliseridemia, dan kolesterol high-density lipoprotein (HDL) rendah. ${ }^{1}$ Noronha dkk. ${ }^{2}$ melaporkan bahwa SM dipengaruhi oleh tingginya stres oksidatif, yang lambat laun berkembang menjadi penyakit vaskular. Volpato dkk. ${ }^{3}$ menambahkan bahwa risiko SM lebih tinggi terjadi pada wanita dibandingkan dengan pria.

Kenyataannya kondisi SM, terjadi peningkatan pengiriman glukosa ke jaringan adiposa. Sel endotel di jaringan adiposa memacu peningkatan uptake glukosa melalui transporter glukosa, sehingga terjadi hiperglikemia yang meningkatkan aktivitas nicotinamide adenine dinucleotide phosphate (NADPH) oksidase, dan produksi senyawa oksigen reaktif mitokondria. Peningkatan senyawa oksigen reaktif (SOR) menyebabkan stres oksidatif dan mengaktivasi sinyal inflamasi, sehingga endotel yang teraktivasi menarik sel proinflamasi makrofag. ${ }^{2}$ Weisberg dkk. ${ }^{4}$ melaporkan bahwa makrofag yang infiltrasi pada jaringan adiposa penderita obesitas, merupakan sumber paling utama sitokin inflamasi. Sejak itu makrofag diketahui memproduksi SOR, karena makrofag yang infiltrasi ke dalam adiposa juga berkontribusi dalam meningkatkan aktivitas NADPH oksidase dan produksi SOR di dalam jaringan tersebut.

Stres oksidatif didefinisikan sebagai kondisi ketidakseimbangan produksi SOR dan status antioksidan endogenus. ${ }^{5}$ Kondisi demikian merupakan komorbiditas obesitas, diabetes melitus, serta gangguan fungsi ginjal. ${ }^{6}$ Tingginya stres oksidatif ditunjukkan oleh rendahnya status antioksidan selular, didukung oleh tingginya produk peroksidasi lipid, namun demikian hingga saat ini belum ada data yang mengungkap status antioksidan selular pada wanita penderita sindrom metabolik. Karena itu penelitian ini bertujuan untuk mengeksplorasi aktivitas enzim antioksidan superoksida dismutase (SOD), katalase, dan glutation peroksidase (GSHPX) pada wanita penderita sindrom metabolik.

\section{Metode}

Penelitian dilakukan di kota Purwokerto, pada bulan Maret-November 2010, dengan melibatkan 30 wanita penderita sindrom metabolik. Seleksi responden diawali dengan survei di Poli Penyakit Dalam RS Umum Daerah Margono Soekarjo Purwokerto, dilanjutkan dengan penelusuran alamat calon responden, kemudian dimotivasi dan diberi penjelasantentang penyakit serta perkembangannya. Responden harus memenuhi kriteria sebagai berikut: kadar gula darah lebih dari normal (puasa $>100$ $\mathrm{mg} / \mathrm{dL} ; 2$ jam postprandial $>126 \mathrm{mg} / \mathrm{dL}$; sewaktu $>200 \mathrm{mg} / \mathrm{dL}$ ), hipertrigliseridemia $(>150 \mathrm{mg} / \mathrm{dL})$, kolesterol HDL rendah $(<50 \mathrm{mg} / \mathrm{dL})$, usia 40-65 tahun, body mass index (BMI) $>25 \mathrm{~kg} / \mathrm{m}^{2}$, tinggal di Purwokerto, dan bersedia menandatangani ikut dalam penelitian (informed consent). Penelitian ini dilengkapi ethical clearance yang diperoleh dari Komisi Etik Fakultas Kedokteran Universitas Gadjah Mada Yogyakarta.

Calon responden diberi kebebasan mengambil keputusan untuk mengikuti atau tidak dalam penelitian ini. Bagi calon responden yang bersedia bergabung dalam penelitian ini, diukur berat badan (dalam $\mathrm{kg}$ ) dan tinggi badan (dalam $\mathrm{m}$ ). Selanjutnya diambil sampel darahnya (sewaktu) sebanyak $2 \mathrm{~mL}$, intravena menggunakan venoject ber-ethylene diamine tetraacetic acid (EDTA). Sebagian sampel darah ditentukan kadar gula (glucocard test strip II), trigliserida dan HDL, sedangkan lainnya dipisahkan plasmanya untuk ditentukan aktivitas enzim antioksidan SOD, katalase, dan GSH-PX.

Pengukuran trigliserida (metode colorimetric enzymatic test) menggunakan gliserol fosfatoksidase (GPO). ${ }^{7}$

Sampel darah sebanyak $10 \mathrm{~mL}$ ditambahkan reagen trigliserida sebanyak $1.000 \mu \mathrm{L}$. Blanko yang digunakan yaitu reagen sebanyak $1.000 \mathrm{uL}$. Masing-masing larutan dihomogenkan, kemudian diinkubasi selama 20 menit pada suhu $20-25{ }^{\circ} \mathrm{C}$ atau 10 menit pada suhu $37^{\circ} \mathrm{C}$. Absorbansi sampel dibaca pada panjang gelombang $500 \mathrm{~nm}$.

Pengukuran kadar HDL menggunakan serum $0,1 \mathrm{~mL}$ dan dimasukkan ke dalam tabung reaksi yang telah berisi $0,25 \mathrm{~mL}$ reagen HDL. Sesudah itu dihomogenkan dan larutan sampel diinkubasi selama 10 menit pada suhu ruangan, kemudian disentrifugasi dengan kecepatan 2.000 rpm selama 10 menit. Supernatan sebanyak $100 \mu \mathrm{L}$ direaksikan dengan $1.000 \mu \mathrm{L}$ reagen kolesterol. Sampel dibaca pada fotometer dengan panjang gelombang $546 \mathrm{~nm}$.

Aktivitas enzim superoksida dismutase (SOD) total plasma pada awalnya dibuat larutan stok SOD. Aktivitas SOD diukur berdasarkan laju penghambatan reduksi ferisitokrom c oleh anion superoksida yang dihasilkan oleh xantin/xantin oksidase. Xantin teroksidasi menjadi asam urat, sedangkan anion superoksida yang terbentuk selanjutnya mereduksi ferisitokrom c. Reduksi ferisitokrom c diamati berdasarkan kenaikan absorbansi pada panjang gelombang $550 \mathrm{~nm}$. Pengukuran aktivitas ini berlangsung pada suhu $25{ }^{\circ} \mathrm{C}$, larutan xantin oksidase harus tetap dalam keadaan dingin sebelum digunakan. Medium reaksi segera disiapkan sebelum pengukuran dengan memasukkan 2,9 mL larutan A (campuran larutan $0,76 \mathrm{mg}$ xantin dalam $10 \mathrm{~mL} 0,001 \mathrm{M}$ $\mathrm{NaOH}$, dengan larutan 1,8 mg sitokrom $\mathrm{c}$ dalam 
$100 \mathrm{~mL}$ bufer fosfat $\mathrm{pH}$ 7,8 tanpa EDTA) ke dalam tabung reaksi $3 \mathrm{~mL}$. Selanjutnya ditambahkan 50 uL larutan baku (kontrol) atau sampel dan divorteks perlahan. Reaksi dimulai dengan menambahkan $50 \mathrm{uL}$ larutan B (xantin oksidase $2,88 \mathrm{mg} / \mathrm{mL}$ dalam bufer fosfat EDTA) dan divorteks perlahan. Diamati perubahan absorban yang terjadi pada spektrofotometer. Untuk blanko digunakan bufer fosfat sebagai pengganti sampel dan sebagai kontrol digunakan akuabides yang proses ekstraksinya sama dengan proses ekstraksi untuk sampel. ${ }^{8,9}$

Aktivitas enzim katalase plasma diawali dengan pembuatan lisat: 200 uL plasma ditambahkan $800 \mathrm{uL}$ larutan $0,5 \%$ triton X-100, kemudian dipersiapkan larutan standar untuk pengukuran sampel. Dibuat larutan induk dengan melarutkan $10 \mathrm{uL}$ katalase dalam $50 \mathrm{~mL}$ bufer fosfat. Larutan standar dibuat dengan melarutkan $0,5 \mathrm{~mL}$ larutan induk dalam 9,5 mL bufer fosfat $(1 / 20)$ dan 0,5 $\mathrm{mL}$ larutan induk dalam $19,5 \mathrm{~mL}$ bufer fosfat $(1 / 40)$. Sebanyak $10 \mathrm{uL}$ lisat dicampurkan dengan $12,5 \mathrm{~mL}$ bufer fosfat. Reaksi mulai terjadi setelah ditambahkan $1 \mathrm{~mL} \mathrm{H}_{2} \mathrm{O}_{2}$. Seluruh larutan divorteks perlahan, lalu penurunan absorbansi dibaca dengan spektrofotometer pada panjang gelombang $240 \mathrm{~nm}$, dengan selang waktu 15 detik, 30 detik, 45 detik, dan 60 detik. Nilai A240 berkisar 0,02-0,10. ${ }^{10}$

Aktivitas enzim glutathione peroxidase (GSHPX) plasma dilakukan dengan cara sebanyak $100 \mathrm{uL}$ plasma diencerkan dengan $200 \mathrm{uL} \mathrm{NaCl}$ fisiologis (larutan 0,85\% NaCl). Diambil $0,1 \mathrm{~mL}$ larutan tersebut dan ditambahkan $0,4 \mathrm{~mL}$ triton-X $0,5 \%$, dan seterusnya disebut hemolisat. Ke dalam tabung uji diambil $100 \mathrm{uL}$ hemolisat dan ditambahkan $100 \mathrm{uL}$ larutan Drabkin lalu dikocok, kemudian ditambahkan 2,6 mL bufer fosfat dan dikocok perlahan. Berturut-turut ditambahkan 0,1 mL NADPH, 0,01 mL GSSG-R, 0,01 mL NaN3, $0,1 \mathrm{~mL}$ GSH, dan dikocok.

Sebelum dibaca laju absorbansinya dengan spektrofotometer pada panjang gelombang $340 \mathrm{~nm}$, ke dalam kuvet silika yang berisi larutan yang akan dibaca absorbansinya ditambahkan $1 \mathrm{~mL} \mathrm{H}_{2} \mathrm{O}_{2}$. Pembacaan absorbansi dilakukan dengan selang waktu 1 sampai 2 menit. Untuk pembuatan blanko digunakan $100 \mathrm{uL}$ akuades sebagai pengganti hemolisat. ${ }^{9}$ Satu unitaktivitas GSH-PX didefinisikan sebagai banyaknya GSH-PX yang diperlukan untuk mengoksidasi 1 umol NADPH per menit.

Semua data yang diperoleh dipresentasikan sebagai rata-rata \pm standard error.

\section{Hasil}

Secara umum responden yang berjumlah 30 wanita dengan rentang usia 40-65 tahun, BMI $27,33-39,95 \mathrm{~kg} / \mathrm{m}^{2}$, kadar gula darah sewaktu 190-357 mg/dL, trigliserida $131-501 \mathrm{mg} / \mathrm{dL}$, dan HDL 29,9-50,9 mg/dL (Tabel 1). Status antioksidan responden ditunjukkan oleh aktivitas enzim SOD, katalase, dan glutation peroksidase dalam plasma (Tabel 2).

\section{Pembahasan}

Dalam penelitian ini, aktivitas enzim SOD rata-rata penderita SM sebesar 7.782,05 Unit $/ \mathrm{mL}$ plasma atau 379,3 Unit/mg protein plasma, lebih rendah dibandingkan dengan wanita sehat dengan usia sama (1.917,31 Unit/mg protein plasma) temuan Winarsi dkk. ${ }^{11}$ Rendahnya aktivitas SOD membuktikan

Tabel 1 Profil Responden

\begin{tabular}{lcc}
\hline \multicolumn{1}{c}{ Karakteristik } & Rentang & Rata-rata \pm SE \\
\hline Usia (tahun) & $40-65$ & $50,4 \pm 3,9$ \\
BMI $\left(\mathrm{kg} / \mathrm{m}^{2}\right)$ & $27,33-39,95$ & $31,9 \pm 1,8$ \\
Gula darah sewaktu (mg/dL) & $190-357$ & $219 \pm 19$ \\
Trigliserida (mg/dL) & $131-501$ & $217,5 \pm 54$ \\
HDL $(\mathrm{mg} / \mathrm{dL})$ & $29,9-50,9$ & $46,6 \pm 4,7$ \\
Kolesterol total $(\mathrm{mg} / \mathrm{dL})$ & & $216,7 \pm 68$ \\
*SE=standard error $; \mathrm{n}=30$ & &
\end{tabular}

Tabel 2 Status Antioksidan Responden

\begin{tabular}{lc}
\multicolumn{1}{c}{ Aktivitas Enzim Antioksidan } & Rata-rata \pm SE \\
\hline SOD (Unit/mg protein) & $379,3 \pm 150$ \\
Katalase (UI/mg protein) & $6,42 \pm 2$ \\
GSH-PX (nmol/g protein) & $804,9 \pm 529$ \\
Kadar MDA (pmol/mL) & $2.943,4 \pm 189,7$ \\
\hline *SE $=$ standard error $; \mathrm{n}=30$
\end{tabular}


tingginya stres oksidatif dalam tubuh, sehingga tidak mampu mengeliminasi banyaknya oksidan (radikal bebas).

Tingginya stres oksidatif juga berkaitan dengan kondisi penderita yang mengalami obesitas, yang memiliki BMI 31,89 kg/m². Pada kondisi obesitas, semakin luas jaringan adiposa dapat menimbulkan kondisi hipoksia (kekurangan $\mathrm{O}_{2}$ ). Pialoux dkk. ${ }^{12}$ menjelaskan bahwa hipoksia yang terjadi kronik meningkatkan stres oksidatif dengan memproduksi SOR berlebihan tanpa mengompensasikannya pada aktivitas enzim antioksidan. Beberapa studi membuktikan bahwa selama hipoksia, produksi SOR meningkat sehingga menekan kerja enzim SOD. Hal ini terjadi karena hipoksia merupakan trigger inhibisi parsial aktivitas rantai transpor elektron yang diakibatkan bocornya elektron dari kompleks I, sehingga mengakibatkan terbentuknya SOR. Yuan dkk. ${ }^{13}$ menambahkan bahwa selama siklus hipoksia/reoksigenasi, SOR terbentuk secara enzimatis melalui jalur xantin oksidase. Di sisi lain SOR juga terbentuk saat iskemia/reperfusi, karena itu tingkat stres oksidatif penderita obesitas semakin tinggi yang berdampak pada rendahnya aktivitas enzim SOD.

Dikatakan pula bahwa aktivitas kompleks $\mathrm{NADPH}$ oksidase merupakan sepertiga bagian jalur produksi SOR selama siklus hipoksiaoksigenasi. ${ }^{14}$ Dengan demikian, dapat diasumsi bahwa makin lama terjadi hipoksia (obesitas yang tidak segera ditangani), makin tinggi kadar stres oksidatif, meningkatkan marker oksidasi lipid, dan menurunkan aktivitas enzim SOD. Peroksidasi lipid merupakan suatu marker kerusakan oksidatif (oxidative injury) yang dipresentasikan sebagai malondialdehid (MDA). Kadar MDA dalam plasma penderita SM sebesar 2.943,4 pmol $/ \mathrm{mL}$, lebih tinggi dibandingkan dengan orang sehat. Malondialdehid merupakan senyawa toksik yang dapat mengganggu keutuhan membran sel, karena itu bila kadarnya tidak segera diturunkan, maka akan mengganggu berfungsinya sel.

Rendahnya aktivitas enzim antioksidan juga terjadi pada enzim katalase $(134,07 \mathrm{UI} / \mathrm{mL}$ plasma atau $6,42 \mathrm{UI} / \mathrm{mg}$ protein). Beberapa studi membuktikan stres oksidatif sistemik berkaitan erat dengan BMI, ${ }^{15,16}$ artinya makin besar BMI, makin tinggi stres oksidatif. Mahadev dkk. ${ }^{17}$ menambahkan bahwa dalam sel adiposa penderita obesitas ditemukan NADPH oxidase 4 (NOX4), yaitu suatu member nitrogen oxides (NOX) yang berperan penting dalam pembentukan $\mathrm{H}_{2} \mathrm{O}_{2}$ (oksidator kuat yang mudah berubah menjadi SOR). Karena itu, semakin tinggi BMI, semakin tinggi pula NOX4 dan terbentuknya $\mathrm{H}_{2} \mathrm{O}_{2}$, sehingga kerja enzim katalase untuk mengkatalisnya makin berat, yang akhirnya menekan aktivitasnya.

Ditegaskan pula bahwa perkembangan SM yang berkaitan dengan obesitas diperantarai lemak yang terakumulasi dalam sel adiposa, maupun kolesterol dalam makrofag yang infiltrasi ke dalam adiposa. Lemak yang terakumulasi dalam bentuk kolesterol total sebesar $216,7 \mathrm{mg} / \mathrm{dL}$, lebih tinggi dibandingkan dengan kadar normal, sehingga menyebabkan disregulasi produksi sitokin IL-6 (interleukin-6), yang ternyata kadarnya sangat tinggi $(22,09 \mathrm{pg} / \mathrm{mL})$. Tingginya sitokin inflamasi tersebut juga meningkatkan produksi SOR dan mempertinggi tingkat stres oksidatif, sebaliknya menekan aktivitas enzim antioksidan, termasuk enzim katalase.

Aktivitas GSH-PX pada penderita SM 16,40 $\mathrm{nmol} / \mathrm{mL}$ plasma atau $0,80 \mathrm{nmol} / \mathrm{mg}$ protein. Aktivitasnya jauh lebih rendah dibandingkan dengan GSH-PX plasma wanita premenopause (65,46 $\mathrm{nmol} / \mathrm{mg}$ protein), temuan Winarsi dkk. ${ }^{9}$ Kerja enzim GSH-PX untuk mengubah $\mathrm{H}_{2} \mathrm{O}_{2}$ menjadi $\mathrm{H}_{2} \mathrm{O}$ dan $\mathrm{O}_{2}$, namun dengan luasnya permukaan tubuh penderita SM, kemungkinan ketersediaan $\mathrm{O}_{2}$ berkurang. Hal seperti ini mungkin karena tumpukan $\mathrm{H}_{2} \mathrm{O}_{2}$ tidak dapat dikonversikan menjadi $\mathrm{O}_{2}$ dengan sempurna, akibat rendahnya aktivitas enzim tersebut.

Pada kenyataannya rendahnya aktivitas enzim SOD, katalase, dan glutation peroksidase didukung oleh tingginya kadar malondialdehid plasma. Kadar MDA penderita SM $2.943,4 \mathrm{pmol} / \mathrm{mL}$, lebih tinggi dibandingkan dengan temuan Dakshinamurty dkk. ${ }^{18}$ yaitu $830 \mathrm{pmol} / \mathrm{mL}$.

Tingginya stres oksidatif juga dipengaruhi usia penderita SM (50,4 tahun). Hal ini terjadi karena bertambahnya usia seseorang, diikuti dengan meningkatnya produksi radikal bebas, sel tubuh mengalami degenerasi, sehingga kerja sel tidak optimal, dan berdampak pada rendahnya aktivitas enzim selular (SOD, katalase, dan glutation peroksidase). Temuan ini mendukung pendapat Hansel dkk. ${ }^{19}$ yang menyatakan bahwa kondisi obesitas secara independen berkorelasi dengan tingginya stres oksidatif dan marker inflamasi. Meningkatnya stres oksidatif dan inflamasi berperan penting dalam inisiasi dan progresivitas penyakit vaskular, yang ternyata kadarnya tinggi ditemukan pada penderita penyakit kardiovaskular.

Mekanisme yang bertanggung jawab terhadap tingginya stres oksidatif pada wanita SM obes belum dapat diketahui, namun yang jelas, jaringan adiposa merupakan salah satu mediator stres oksidatif dan inflamasi yang penting karena berkontribusi pada produksi SOR dan sitokin proinflamasi, termasuk IL-6. ${ }^{20}$ Ekspresi serta sekresi mediator tersebut meningkat seiring dengan besarnya sel adipose yang digambarkan oleh distribusi lemak tubuh. Terakumulasinya kelebihan lemak viseral (bukan lemak subkutan), berkaitan dengan makin tingginya produksi sitokin inflamasi. Karena itu, dapat 
diyakini bahwa besarnya sel adiposa merupakan faktor utama yang mempengaruhi rendahnya status antioksidan wanita penderita SM obes.

Stres oksidatif penting dalam patofisiologi diabetes melitus/kardiovaskular, karena itu perlu dicari upaya untuk menghambat perkembangan kondisi SM yang dapat menurunkan berat badan penderita, dan selanjutnya akan berdampak pada sel adiposa, perbaikan hipoksia, serta menurunnya tingkat stres oksidatif yang akhirnya meningkatkan aktivitas enzim antioksidan.

Simpulan, status antioksidan pada penderita SM sifatnya rendah yang ditunjukkan oleh rendahnya aktivitas enzim SOD, katalase, dan glutation peroksidase, serta didukung oleh tingginya kadar MDA plasma.

\section{Ucapan Terima Kasih}

Penulis berterima kasih kepada Direktorat Jenderal Pendidikan Tinggi, Kementerian Pendidikan Nasional atas pendanaan penelitian ini melalui Proyek Hibah Bersaing, No. 020/SP2H/PP/DP2M/ III/2010 Tanggal 1 Maret 2010.

\section{Daftar Pustaka}

1. IDF (International Diabetes Federation). The IDF Consensus Worldwide Definition of the Metabolik Syndrome. 2009. [diunduh 29 April 2009]. Tersedia dari: http://www.idf.org.

2. Noronha BT, Li JM, Whetcroft SB, Shah AM, Kearney MT. Inducible nitric oxide synthase has divergent effects on vascular and metabolic function in obesity. Diabetes 2005;54:1082-9.

3. Volpato S, Guralnik JM, Ferrucci L, Balfour J, Chaves P, Fried LP, dkk. Cardiovascular disease, interleukin-6, and risk of mortality in older women: the women's health and aging study. Circulation. 2001;103:947-53.

4. Weisberg SP, McCann D, Desai M, Rosenbaum M, Leibel RL, Ferrante (Jr) AW. Obesity is associated with macrophage accumulation in adipose tissue. J Clin Invest. 2003;112:1796808.

5. Barcelo A, Barbe F, de la Pena M, Vila M, Perez G, Pierola J, dkk. Antioxidant status in patients with sleep apnoea and impact of continuous positive airway pressure treatment. J Eur Respir. 2006;27:756-60.

6. Sharma SK, Kumpawat S, Goel A, Banga A, Ramakrishnan L, Chaturvedi P. Obesity, and not obstructive sleep apnea, is responsible for metabolic abnormalities in a cohort with sleepdisordered breathing. Sleep Med. 2007; 8:12-7.

7. Astawan M, Tutik W, Anzs BH. Pemanfaatan rumput laut sebagai sumber serat pangan untuk menurunkan kolesterol darah tikus. J Hayati.
2005;12(1):23-7.

8. Wood LG, Fitzgerald DA, Lee AK, Garg Manohar L. Improved antioxidant and fatty acid status of patients with cystic fibrosis after antioxidant supplementation is linked to improved lung function. Am J Clin Nutr. 2003; 77:150-9.

9. Winarsi H, Muchtadi D, Zakaria FR, Purwantara B. Respons hormonal -imunitas wanita premenopause yang diintervensi minuman fungsional berbasis susu skim yang disuplementasi isoflavon kedelai \& $\mathrm{Zn}$ sulfat. J Teknol Ind Pangan. 2004;15:28-34.

10. Winarsi H, Hernayanti, Purwanto A, Sukanto. Profil dan status antioksidan wanita penderita candidiasis di Purwokerto. M Med Indones. 2006;41:108-12.

11. Winarsi $H$, Yuniati $A$, Purwanto A. Deteksi aging pada wanita berdasar status antioksidan SOD sebagai upaya pengelolaan sumberdaya manusia. Seminar Nasional "Peran Biosistematika dalam Pengelolaan Sumberdaya Hayati Indonesia", Purwokerto, 12 Desember 2009.

12. Pialoux V, Hanly PJ, Foster GE, Brugniaux JV, Beaudin AE, Hartmann SE, dkk. Effects of exposure to intermittent hypoxia on oxidative stress and acute hypoxic ventilatory response in humans. Am J Respir Crit Care Med. 2009; 180:1002-9.

13. Yuan G, Adhikary G, McCormick AA, Holcroft JJ, Kumar GK, Prabhakar NR. Role of oxidative stress in intermittent hypoxiainduced immediate early gene activation in rat PC12 cells. J Physiol. 2004;557:773-83.

14. Abramov AY, Scorziello A, Duchen MR. Three distinct mechanisms generate oxygen free radicals in neurons and contribute to cell death during anoxia and reoxygenation. J Neurosci. 2007;27:1129-38.

15. Keaney (Jr) JF, Larson MG, Vasan RS, Wilson PWF, Lipinska I, Corey D, dkk. Obesity and systemic oxidative stress: clinical correlates of oxidative stress in the Framingham Study. Arterioscler Thromb Vasc Biol. 2003;23:434 9.

16. Olusi SO. Obesity is an independent risk factor for plasma lipid peroxidation and depletion of erythrocyte cytoprotective enzymes in humans. Int J Obes Relat Metab Disord. 2002;26:1159 64.

17. Mahadev K, Motoshima H, Wu X, Ruddy JM, Arnold RS, Cheng G, dkk. The NAD(P) $\mathrm{H}$ oxidase homolog Nox4 modulates insulinstimulated generation of $\mathrm{H}_{2} \mathrm{O}_{2}$ and plays an integral role in insulin signal transduction. Mol Cell Biol. 2004;24:1844-54.

18. Dakshinamurty KV, Rao PVLN S, Saibaba 
Hery: Aktivitas Enzim Superoksida Dismutase, Katalase, dan Glutation Peroksidase Wanita Penderita Sindrom Metabolik

KSS, Sheela RB, Venkataramana G, Shyam $\mathrm{C}$, dkk. Antioxidant status in patients on maintenance haemodialysis. Indian J Nephrol. 2002;12:77-80.

19. Hansel B, Giral P, Nobecourt E, Chantepie S, Bruckert E, Chapman MJ, dkk. Metabolic syndrome is associated with elevated oxidative stress and dysfunctional dense high-density lipoprotein particles displaying impaired antioxidative activity. J Clin Endo Metab. 2004;89:4963-71.

20. Kershaw EE, Flier JS. Adipose tissue as an endocrine organ. JCEM. 2004;89:2548-56. 